\title{
Exploring Objectification of Colonial Subjects in J. M. Coetzee’s Foe
}

\author{
Seema Dagar \\ Banasthali University
}

\begin{abstract}
Objectification, a phenomenon, in Foucault's term, can be possible through "dividing practices” which divide the subject from others. It can be seen when the subject can be differentiated within the realms of good and bad, rich and poor, and powerful and powerless. Subject in Foucault's notion is the diagnosis of what we are and how the power subjected the subject. It also echoes the idea of Stephen Best where he explains that a muted slave has not simply been objectified, but thingified. J. M. Coetzee's Foe traverses through the conduit of objectification of Friday, cannibals slave who has been muted by his master. This novel articulates the testament of power and latent limitations of language, language as an expression of truth and the antithesis of silence. Friday's tongulessness is the mystery behind his submission and subjugation to slavery. It can be explored through the power of textaulity which has been controlled by the powerful. This novel intends to look upon the marginalized and voiceless condition questions the writing process of Susan Barton. It also echoes the phenomenon of Foucaultian concept of silence and resistance which has been tool to negate hegemonic power and it gives power for not being subjectivized. Therefore, it initiates the possibility of adaptation of the process of unbecoming to finish the authority of apparatuses as echoed by Althusser. Further, it portrays the hegemony in the construction of colonial subject by controlling the power of language, freedom to write and economic freedom. The paper in the context intends to examine the complex process of translating Friday into an object through the process of objectification.
\end{abstract}

Keywords: objectification, tongulessness, submission, subjugation, apparatuses

Objectification is possible through oppression by power and epistemic violence. It is a phenomenon, in Foucault's term, can be possible through "dividing practices” which divide the subject from others. Subject can be differentiated within the realms of good and bad, rich and poor, and powerful and powerless. Subject in Foucault's notion is the diagnosis of what we are and how the power subjected the subject and it has authority to subjugate and turn one into a subject. It has capacity to impose a new identity by transplanting the law of truth. He talks about the truth of power that is totally controlled by the hegemonic realities which further affects the social, economic, cultural, and historical realities of postcolonial subjects. Power is exploitative in nature one who holds power he/she will exercise the power to control others. The phenomenon of Foucault's works always focused upon how modern civilization creates and controls human subjects through institutions such as prisons, hospitals, education, and knowledge system. How these different factors exercise the execution and distribution of power, similarly as Althusser (1971) avers the fact that it is the texture of socio political factors

Seema Dagar, research scholar, Department of English and Modern European Languages, Banasthali University, India; main research fields: Postcolonialism, Race Theory, Marxism, and Gender Studies. 
which constitutes the identity of a person and he explains it through "Repressive State Apparatuses" or RSA's "the police, the courts the prisons; but also the army... and above this ensemble, the head of state, the government and the administration" (137). Further, "Hegemony" is the term used by the theorist Antonio Gramsci (1891-1937) to convey "the extent to which belief systems are thoroughly naturalized that dominates the consciousnesses of individuals.” Power as a discourse in Foucault’s (1982) views:

This form of power applies itself to immediate everyday life which categorizes the individual, marks him by his own individuality, attaches him to his own identity, imposes a law of truth on him which he must recognize and which others have to recognize in him. It is a form of power which makes individuals subjects. There are two meanings of the word "subject:" subject to someone else by control and dependence; and tied to his own by a conscience or self-knowledge. Both meanings suggest a form of power which subjugates and makes subject to. (781)

Concept of power in Foucaultian sense is juridical which is based on the law and taboo and can be seen as restrictive and repressive. In his seminal text The History of Sexuality (1978), he states that subjects can be operated not "by right but technique, not by law but by normalization, not by punishment but by control" (87). He insists that "power is everywhere; not because it embraces everything, but because it comes from everywhere." It is "simply the over-all effect that emerges from all these mobilities" (93). Paul Rabinow's The Foucault Reader (1984) states in Foucault's view with regard to power, where he says power traverses in society from one to another:

In Discipline and Punish, what I wanted to show was how, from the seventeenth and eighteenth centuries onward, there was a veritable technological take-off in the productivity of power. Not only did the monarchies of the classical period develop great state apparatuses (the army, the police and fiscal administration), but above all there was established in this period what one might call a new "economy" of power, that is to say procedures which allowed the effects of power to circulate in a manner at once continuous, uninterrupted, adapted, and "individualized" throughout the entire social body. (61)

It depicts that not only state apparatuses but economic reality also controls the identity of postcolonial subjects. As Marx and Engels in Manifesto of the Communist Party (1848) have argued that "Man's ideas, views, and conceptions, in one word, man's consciousness changes with every change in the condition of his material existence, in his social relations and his social life" (489). Marx also coined the term "economic determinism" which stands for the identity which can be determined by the economy. Thus, "it is not the consciousness of men that determines their existence, but their social existence that determines their consciousness" as Marx articulated in "Preface" (1859). Further, power according to Foucault can be exercised on the free subjects. As Donald E. Hall (2004) articulates power in Foucaultian sense "power is never exercised in a top-down fashion. Power circulates, is appropriated and deployed, and requires a multidimensional model to grasp it in its complexity” (93). Jean-Paul Sartre in his preface to Frantz Fanon's The Wretched of the Earth (1963) commented on the colonizing power of Europe and how they represented the colonized nations as puppet:

[...] they branded them, as with a red-hot iron, with the principles of western culture; they stuffed their mouths full with high-sounding phrases, grand glutinous words that stuck to the teeth. After a short stay in the mother country they were sent home, white-washed... the mouths opened by themselves; the yellow black voices still spoke of our humanism but only to reproach us with our humanity... at first with proud amazement. What? They are able to talk by themselves? Just look at what we have made of them. (7) 
Quest of power has given birth to phenomenon of empire and desire of extending empire has made gulf between master and slave. Imperialism is an ideological concept which upholds the legitimacy of economic and political power of one country on another. It further gives birth to capitalism and colonialism. In capitalism, the colonizer controls the private ownership, capital, and economic decisions. Colonialism means when a powerful country attacks and gradually starts controlling and influencing the cultural, economical, and linguistic realities of weaker countries. The colonial masters always oppress the colonized or enslaved subject by dividing practices. Slaves were divided on the bases of history, gender, race, class, and epistemic formation. Colonizer not only colonized them but also curtailed their historical, cultural, and social realities. In the process of colonization, they colonized the complete humanist tradition because the colonizers treat colonized subjects as object. Power is the best tool to dominate the powerless and treat them as objects. Postcolonialism is a political, cultural, economic, social, and linguistic phenomenon in which the process of colonization is explained and further; it is also expounded that how the colonized mind can get itself free from those burdens through which the colonizer colonized the kind of colonized country. Frantz Fanon in The Wretched of the Earth (1963) has explored that on the one hand how the white Africa is thought to have cultural tradition and on the other Black Africa has been looked as "inert, brutal, and uncivilized" (161). The term race established on the basis of color difference and color become the means of distinguishing between people and groups. There are some prominent writers who totally neglected the capability of blacks, to be a writer, or to have some historical or cultural roots to claim. This negligence has been initiated by Hume, Jefferson, Hegel, and Kant. Hume in his essay "Of National Characteristics" (1748) states that the Negroes were "naturally inferior to the whites" and it was on the basis of "nature" that Negroes had "no arts, no sciences" (60). Kant also supported the idea of Hume by correlating "blackness" and "stupidity.” Further, Thomas Jefferson "completely denied that the blacks were capable of poetry” (61). In opposition to this, H. L. Gates (1992) points out that Hegel was echoing Hume, Kant, and all the writers who think that "Absence of memory," a collective, cultural memory. He summarizes connections between reason, writing, history, and humanity. In addition, Fanon's Black Skin and White Masks (1967) reinstates the fact that the translation of the repression and trauma that the colonized marginals have experienced can only be the endeavor of the process of translation. Further, Young expounds

In Black skin, White Masks, he argues that black man and woman have been translated not only as colonial subjects in the regime of French imperialism, but also internally, psychologically: Their desires have been changed into another form, carried across into the desire for whiteness through a kind of metempsychosis... they have black skin with white mask. (144)

J. M. Coetzee's Foe (1986) deals with the preoccupied notion of objectification of colonial subjects through Friday and Susan Barton. On the one hand, Friday who is cannibals slave and has been muted by his master and Susan Barton who is voiceless and doesn't have authority to write his own work, on the other. This novel depicts that how testament of power and objectification control the becoming of colonial subjects. Coetzee with his protagonists tries to fabricate the muteness which is the gift of colonizer and suppress the voice of colonial subjects from time immemorial. Friday due to his muteness isn't able to voice for himself. His tongulessness was the proof of the brutal nature of masters. Therefore, Susan tries to teach him how to speak and write so that he can be liberated from slavery. The story of slavery and voice of the suppressed can be heard by the cruel world. She makes two sketches to unravel the mystery behind his cutting of tongue but everything was useless: 
[...] many stories can be told of Friday's tongue, but the true story is buried within Friday, who is mute. The true story will not be heard till by art we have found a means of giving voice to Friday... Friday has no commands of words and therefore no defence against being re-shaped day by day in conformity with the desires of others. I say he is a cannibal and he becomes a cannibal; I say he is a laundryman he becomes a laundryman. What is the truth of Friday? $(118 ; 121)$

It also echoes the phenomenon of Foucauldian concept of silence and resistance which has been tool to negate hegemonic power and it gives power for not being subjectivized by negating the symbolic order. Silence is a way of resistance as it has been depicted by Michael Foucault in his Madness and Civilization: A History of Insanity in the Age of Reason (1961), he argued that the only possibility lies with the subject by adopting the process of unbecoming. Here unbecoming means to finish the authority of state apparatuses. Further, in The Archeology of Knowledge (1969), Foucault states that one can adopt the process of unbecoming by unlearning of knowledge. Unlearning the language can be done by the process called silence because silence is tool to negate hegemonic power and silencing gives power not to be subjectivized. Silencing can be an act of liberation in Bhabha views and identity is like a hymen (mixture of two) or pharmakon. It can be seen through Friday "Therefore the silence of Friday is a helpless silence. He is the child of his silence, a child unborn, a child waiting to be born that cannot be born... Because he is helpless, said I-because London is strange to him. 'Because he would be taken for a runaway, and sold, and transported to Jamaica'” (122-8). Friday's muteness was his resistance against his master. He doesn't want to learn to read and write because he doesn't want to be the part of the discourse of colonial master. Barton wants to teach him her language but Friday's silence echoes his disinterestedness in their discourse. As last paragraph of the novel articulates "but this is not a place of words... It is the home of Friday" (157).

G. C. Spivak, in her famous intervention "Can the Subaltern Speak?” (1988), tries to voice the subalterns because they have been denied to voice. The term "subaltern" is articulated by Antonio Gramsci anything which is suppressed on any dimension. It can be based upon sex, class, race, language, and gender dimensions. She articulates that West has always been represented as a source of power and it has been controlling the East by the law, politics, economy, and ideology. Eurocentric model also controlled the language of East because language is the major instrument to control the identity of subaltern. Subalterns may copy the language of power but not the language of intellect. Therefore, she introduced the term "epistemic violence" which introduces the western discourse of knowledge to control the mind of colonized. Further, Fanon (1963) articulates how the colonized are the objects of the speech of colonizer. Colonial history is nothing but the echo of the oppression of culture and native voice and colonizers played the double game by not only settling but exploiting them at the same time:

[...] our values and the true facts of their lives did not hang together, and that they could neither reject them completely nor yet assimilate them... "You are making us into monstrosities; your humanism claims we are at one with the rest of humanity but your racist methods set us apart”... The status of "native” is a nervous condition introduced and maintained by the settler among colonized people with their consent. $(8 ; 17)$

Colonizers introduce the intellectual knowledge system to control their mind and to exercise power. Spivak also introduced two terms for subalterns (a) verterten —speaking for (b) darstellen-re-present, in the process of "speaking for" they cannot voice themselves and in "re-presentation" their capacity to represent themselves is completely neglected. She takes up the process through which the metanarrative (powerful) controlled the local narrative (marginal) and did not allow to write for themselves instead they were given a representation of object by those metanarrative. Therefore, the complexity of thought is not understood by the 
marginals and the object of the production of knowledge never becomes the subject of it. Foe also echoes the objectification of female protagonist Susan who is not authorized to obtain the right to write her own story. She was asked to curtail truth from her story so that her story can be modified according to Mr. Foe. It depicts how the economic condition and gender play an important role to voice for her. Susan is doubly suppressed on the one hand being female and on the other for not having strong economical background:

[...] I am a free woman who asserts her freedom by telling her story according to her own desire... In the beginning, I thought I would tell you the story of the island and, being done with that, return to my former life. But now my life grows to be story and there is nothing of my own left to me... The story I desire to be known by is the story of the island. You call it an episode, but I call it a story in its own right. (121; 131-3)

Homi Bhabha in his Location of Culture (1994) reinstates the fact how the colonizers have subjugated the colonized natives through power and turned them into an object. The process of the object formation or making of colonial slaves can be seen as a result of power politics. In this process, the colonial masters with the structure of power or authority turn the colonized self into objects and prove themselves as subject. Colonial subject is signifier (image) and the signified (meaning) changed when the master changed. "Mimicry" shouldn't be complete enslavement of the mind by the hegemonic power of the colonizer. Mimicry is a process which allows colonized to understand or negotiate with a particular cultural tradition in order to interrogate and to find out some creative and model knowledge, tradition or culture:

[a] range of contemporary critical theories suggest that it is from those who have suffered the sentence of history—subjugation, domination, diaspora, displacement—-that we learn our most enduring lessons for living and thinking. There is even growing conviction that the affective experience of social marginality... transforms our critical strategies. (172)

Edward. W. Said wrote first text on postcolonisation Orientalism (1978) which represented east as an integral part of "European material civilization and culture" (2) and "a place of romance, exotic beings, haunting memories and landscapes, remarkable experiences” (1). Orient was nothing but the set of ideology imposed by occident (west) on east. The desire of extending empire leads them to subjugate orient on the level of knowledge, linguistic, cultural, historical, social, and economic discourse:

“Orient” and "Occident” are man-made. Therefore, as much as the west itself, the orient is an idea that has a history and tradition of thought, imagery, and vocabulary that have given it reality and presence in and for the West... The relationship between occident and orient is a relationship of power, of domination, of varying degrees of a complex hegemony. (5)

Further, Foucault articulates in Order of Things (1966), powerful countries create the system of order. This order is not natural but decided by powerful to rule over the marginal. It is possible through implanting their system of knowledge and controlling the discourse of knowledge. Similarly, Enlightenment by Kant was thought to dispel the orthodoxy of religion and bring people outside from the darkest side of religion. Further, Theodor W. Adorno and Max Horkheimer argued that enlightenment was used to control the knowledge system of colonial nation. Interpellation used by Althusser meant the construction of mind and turning someone into subject. Said also argued that the construction of writer's conscious is controlled by the hegemonic realities therefore our history is Problematic. In Althusser's sense, Problematic is a process in which the knowledge of geography, sociology, economics, political systems, anthropology etc., has been formed by colonial masters and manifested in different light: "Orientalism is not a mere political subject matter or field that is reflected passively by culture, scholarship, or institutions; nor is it a large and diffuse collection of texts about the Orient; 
nor is it representative and expressive of some nefarious 'western' imperialist plot to hold down the 'oriental' world" (12).

Author has the authority to modulate the historical realities therefore Said argues for the authentification of historical sources. Context of the text depends upon the authority of the master and how a text is formed in economic, linguistic, cultural, and historical realities of that time

There is nothing mysterious or natural about authority. It is formed, irradiated, disseminated; it is instrumental; it is persuasive; it has status; it establishes canons of taste and value; it is virtually indistinguishable from certain ideas it dignifies as true, and from traditions, perceptions, and judgments it forms, transmits, reproduces... All these attributes of authority apply to Orientalism. (19-20)

John Plotz in his famous intervene "Can the Sofa Speak? A Look at Thing Theory" (2004) articulates that things are culturally defined. Culture gives meaning to a thing or object. Thing theory approached to the margins, of language, cognition, and material substance. His essay also echoes the idea of Stephen Best (The Fugitive Properties, 2004) where he explains that a muted slave has not simply been objectified, but thingified. Slavery not only thingified the personality, face, voice, and talent but whole body has been turned into thing which parted the real essence of host body:

American jurisprudence: The underlying historical trajectory being, in his account, the vitiation of the oft-invoked ideal of "equality" once it becomes clear that such equality is conditioned by the willingness of the law to treat slaves as property and hence to continue to imagine even "inalienable” possessions like one’s voice or one's image as part and parcel of the same contractable property. (115)

Further, it reinstates the fact that how American law adheres the slave equal to property. The logic of justice and equality is mere a false representation for slaves because they cannot transcend themselves without these rights. Friday's tongulessness is the mystery behind his submission and subjugation to slavery. The paper in the context intends to examine the complex process of translating Friday into an object through the process of objectification:

Friday's desires are not dark to me. He desires to be liberated, as I do too. Our desires are plain, his and mine. But how is Friday to recover his freedom, who has been slave for all his life? That is true question. Should I liberate him into the world of wolves and expect to be commended for it?... Even in his native Africa, dumb and friendless, would he know freedom? There is an urging that we feel, all of us, in our hearts, to be free; yet which of us can say what freedom truly is?.. As to Friday, how can Friday know what freedom means when he barely knows his name? (148-9)

Arjun Appadurai in his famous text on thing theory The Social Life of Things: Commodities in Cultural Perspective (2011) articulates that commodities also have social life because the value we give to commodity is totally dependent of politics. Any commodity turns into a thing on the basis of its social existence and value of things is based upon its presence.

[...] we have to follow the things themselves, for their meanings are inscribed in their forms, their uses, their trajectories. It is only through the analysis of these trajectories that we can interpret the human transactions and calculations that enliven things. Thus, even though from a theoretical point of view human actors encode things with significance, from a methodological point of view it is the things-in-motion that illuminate their human and social context. (5)

Thus, paper in nutshell explicates the fact that hegemony plays an important in construction and objectification of colonial subjects. In the process of colonization, the colonial subjects are enslaved and interpellated by controlling the power of knowledge system, language, freedom to write and economic freedom. 
As it has been explained by several theorists that colonial subjects gradually in the process of colonization get translated into an object from subject, the journey doesn't stop here, in fact they further translate themselves into a thing because their subjectivities and self are not powerful to reflect and represent themselves rather they become an object of the desire of the self which turns them into other. Those others are gradually treated as the thing. The novel has also explained the entire journey of the character where the character experienced all possible kind of subservience which turns the character into a thing. Further, it may be stated that an apposite application of Brown's “Thing Theory” in the understanding of the novel Foe by J. M. Coetzee may establish the fact that how the colonial slaves gradually become a thing which is devoid of its own existence or the ontological realities.

\section{Works Cited}

Althusser, Louis. Lenin and Philosophy and Other Essays. New York: Monthly Review Press, 1971.

Appadurai, Arjun. The Social Life of Things: Commodities in Cultural Perspective. Cambridge: Cambridge University Press, 1988.

Bhabha, Homi K. The Location of Culture. London: Routledge, 2012.

Coetzee, J. M. Foe. London: Penguin Books, 1986.

Fanon, Frantz. Black Skin, White Masks. Trans. Charles Markmann. New York: Grove Press, 1967.

---. The Wretched of the Earth. Trans. Constance Farrington. New York: Grove Press, 1963.

Foucault, Michel. The History of Sexuality: An Introduction. Trans. Robert Hurley. Harmondsworth: Penguin, 1978.

Gates, Henry Louis Jr. “Writing, 'Race,’ and the Difference It Makes.” Loose Canons: Notes on the Culture Wars. New York and Oxford: Oxford University Press, 1992. 45.

Hall, Donald E. Subjectivity. New York: Routledge, 1960.

Marx, Karl, Friedrich Engels, and Samuel Moore. The Communist Manifesto. New York: New York Labor News Company, Vol. 6008, 1959.

Plotz, John. “Can the Sofa Speak? A Look at Thing Theory.” Criticism 47.1 (2005): 109-18.

Rabinow, Paul. The Foucault Reader. New York: Pantheon Books, 1984.

Said, Edward W. Orientalism. India: Penguin Random House India, 1978.

Spivak, Gayatri Chakravorty. “Can the Subaltern Speak?” Marxism and the Interpretation of Culture. Eds. Cary Nelson and Lawrence Grossberg. Urbana: University of Illinois Press, 1988. 66-111.

Young, Robert J. C. Postcolonialism: A Very Short Introduction. Indian Edition, New Delhi: Oxford University Press, 2005. 